\title{
Civil Society and Tobacco Control in Indonesia: The Last Resort
}

\author{
Harsman Tandilittin and Christoph Luetge*
}

Business Ethics, Technische Universitaet Muenchen, Marsstrasse 20-22, D-80335 Munich, Germany

\begin{abstract}
In many countries around the world, the mechanisms of civil society have become very commonplace. Large companies are under constant pressure from civil society organizations to change their policies, strategies and approaches. The tobacco industry in particular is under heavy pressure in many parts of the world. Smoking has been prohibited in many public as well as private or semi-private areas in a large number of countries. However, while smoking as an addiction seems to be declining in some countries, in others it is not. This paper presents an example of a country (Indonesia) in which smoking is still on the rise. We discuss how mechanisms of civil society are a chance to at least improve the situation and effectively combat a grave social problem.
\end{abstract}

Keywords: Civil society organizations, Tobacco control barriers, Tobacco control research, Tobacco control funds, Vote for tobacco control.

\section{INTRODUCTION}

Tobacco has led to a global epidemic of tobacco-related diseases and young addicted smokers. As a result, the World Health Organization (WHO) has signed the Framework Convention on Tobacco Control (FCTC) to protect nonsmokers from exposure to second-hand cigarette smoke and to prevent adolescents from taking up cigarettes [1]. The stagnation of tobacco control progress has resulted in soaring numbers of smokers and tobacco related-diseases in Indonesia. Indonesia is the only country in the Asia Pacific Region that has not yet ratified the FCTC. The Global Youth Tobacco Survey reported that smoking prevalence among Indonesian teenagers sharply rose from $12.6 \%$ in 2006 to $22.5 \%$ in 2009 [2, 3]. According to the Global Adult Tobacco Survey (GATS) in 2011, Indonesia has the highest smoking prevalence in the world with $67.4 \%$ of men and $4.5 \%$ of women comprising $36.1 \%$ of the population. It is approximated that in 2010 about 235,000 Indonesians died due to tobacco related-diseases [4].

Indonesia has been implementing tobacco regulations since 1999, but the reality of tobacco use goes in the opposite direction. Tobacco consumption skyrocketed from about 173 billion cigarettes in 2004 to 265 billion cigarettes in 2010. Loss of tobacco tax revenue is usually used to argue against strong tobacco control. Some research shows that the loss of life to tobacco-related diseases far outweighs the tobacco tax revenue $[5,6]$. However, the Indonesian government has not implemented stricter tobacco regulations mostly due to its overlaps with economic, political, legal, and social considerations; thus, tobacco control policies must consider the perspectives of a broad range of stakeholders.

*Address correspondence to this author at the Business Ethics, Technische Universitaet Muenchen, Marsstrasse 20-22, D-80335 Munich, Germany; Tel: +49-89-289-25130; Fax: +49-89-289-25133;

E-mail: Luetge@tum.de
Civil society organization is one of the most important non-government actors in the success of negotiation and implementation of tobacco control policies around the world [7]. In this paper, we first present an overview of the socioeconomic impacts of tobacco and the health hazards of smoking. We then provide an overview of the changes to tobacco control regulations and the political environment behind it. Thereafter, we examine four potential barriers to tobacco control in Indonesia: smoking as a social norm, the incapability of uneducated people and adolescents to make rational decisions, the political aspect and the lobby of the tobacco industry against tobacco control, and the behavior of cigarette retailers. We discuss the relevance of civil society organizations in resolving the tobacco control barriers in Indonesia and conclude with several suggestions to support tobacco control in Indonesia.

\section{SOCIO-ECONOMIC IMPACTS OF TOBACCO}

\subsection{The Economy of Tobacco and Smoking}

Given its large population and smoking prevalence, Indonesia was ranked third among countries with the highest smoker population globally at 61.4 million adults as active smokers [4]. The tobacco excise tax is one of the important sources of government revenue, from which about $6.1 \%$ of annual government revenue is drawn (Indonesian Minister of Finance, 2012) [8]. Smokers spent about IDR 174.8 Trillion or $1.7 \%$ of GDP on cigarettes in 2011. Research shows that the total contribution of cigarette industries toward the Indonesian gross domestic product (GDP) in 2005 was about 1.5\% (Rachmat, 2010) [9]. Moreover, the tobacco plantations and cigarette industry accounted for only about $0.9 \%$ of the total workforce in Indonesia [10]. Unfortunately, the total 
loss of life due to tobacco-related diseases went up sevenfold of GDP [6].

\subsection{Smoking and Poverty}

The tobacco industry has made a significant contribution to government revenue and employment. In contrast, the average real-wage in the cigarette industry is always below the nominal national wage, and it has even fallen below the poverty line since 2008. Scientific evidence confirms that smoking has created a poverty cycle among Indonesian smokers. Households with smokers spent $11.5 \%$ of their household income on cigarettes compared to only 11\% spent on fish, meat, eggs, and milk [11]. Poor urban family smokers spent $22 \%$ of their weekly income on cigarettes [12]. At the same time, nationally, the lowest-income families consume on average 12 cigarettes daily. In other words, they spend up to $40 \%$ of their income on cigarettes [4].

Some research shows that smoking has had a huge impact on health and education among the lowest-income families in Indonesia. The research has revealed that low spending on health and nutrition among poor families has a significant impact on the increase in malnutrition in toddlers [1214]. The mortality rate of children and infants is also higher in families in which the father is a smoker than in those with a nonsmoking father [15]. Premature death of fathers as a family breadwinner has also increased the rate of school drop-outs [11].

\subsection{Health Hazards of Smoking}

Kreteks are the most preferred type of cigarette by $88.1 \%$ of Indonesian smokers [4]. They are made from 30-40\% cloves and contain special flavoring ingredients called "sauces," which are unique to each brand. From the 33 Indonesian kretek brands tested in 2007, all contained eugenol, 13 brands contained anethole, and coumarin was found in 19 brands [16]. Cloves naturally contain eugenol which is linked to acute, chronic, and behavioral health effects when inhaled [17]. Anethole and coumarin are flavoring and sweetener agents; thus, they are likely contained in the kretek sauce. Anethole has been proven to be toxic to the liver and has been found to cause cancer and mutate animal cells [18]. In large doses, coumarin results in toxic effects on the nervous system, blood vessels, and liver [19].

During the manufacturing process, the sauces that contain hundreds of chemical ingredients are added the cigarette to provide a special taste. While these additives may be safe when ingested, this is not the case when they are inhaled in smoke. Some of the carcinogenic additives found in cigarettes are ammonia, acetaldehyde, benzyl acetate, and humectants [20]. Indeed, Indonesian tobacco companies are not required to disclose additives to tobacco products. They even argue that the sauce is a secret of a successful brand [21].

In 2008 the WHO established that tobacco is the single largest cause of preventable death in the world. The WHO projects that, in 2030, tobacco-related diseases will be causing more than 8 million deaths globally per year with $80 \%$ in developing countries given the rapidly increasing tobacco use there. In 2010, it is estimated that tobacco-related diseas- es accounted for $12.4 \%$ of total deaths in Indonesia [4]. The majority of lung cancers, about $90 \%$, are caused by smoking cigarettes [22]. In addition, nearly half of smokers lost their lives on average after 10-15 years of smoking [23, 24]. The life expectancy of Indonesian people is nearly 71 years; therefore, about $50 \%$ of Indonesian smokers will most like die between the ages of 55 and 60. Due to premature mortality and disabilities in 2010, the total loss of disabilityadjusted life years (DALYs) in Indonesia was more than 3.5 million DALYs [4].

\section{TOBACCO CONTROL IN INDONESIA}

The Indonesian government under Suharto’s authoritarian regime had no intention of trying to regulate smoking and cigarette marketing. In contrast, the government consistently supported the local tobacco companies. Surprisingly, only two of the Suharto family members were directly involved in the tobacco industry [25]. After the Suharto era, or reformation era, President B.J. Habibie signed the first Indonesian tobacco regulation entitled $\mathrm{PP} / 81 / 199$. This first tobacco control regulation were succeeded with regulations 38/2000 and 19/2003. Unfortunately, insignificant changes in these regulations indicated the stagnation of tobacco control in Indonesia which was due to the political and economic aspects of the tobacco industry resulting in the reluctance of the government to enforce strict regulations [26].

The last amendment to the tobacco control regulation, number 109/2012, also did not actually accommodate the WHO Framework Convention on Tobacco Control, and this regulation even suffered a setback. Tobacco advertising in electronic media is prohibited by the first decree but is allowed by the last amendment during a limited period (21.30 p.m.-05.00 a.m. local time). Some progress in tobacco control was accommodated in the last decree, such as special protection for children and pregnant women. This regulation prohibits the sale of cigarettes to children and pregnant women, but provides only administrative sanctions for its violation. A few anti-smoking groups proposed that the purchase and sale of cigarettes in bars should be prohibited to prevent smoking initiation among adolescents and poor people. However, the proposal was not accommodated in the last decree [27], and administrative sanctions for violations render the regulation extremely weak. Thus, it is easily violated by manufacturers, advertisers, and retailers [28]. The good news of the last decree, however, is that civil society organizations can supervise implementation of the decree. Under this context, we will proceed to discuss the potential barriers of tobacco control regulation and the relevance of civil society in Indonesia.

\section{BARRIERS TO TOBACCO CONTROL REGULA- TION}

\subsection{Smoking has Become a Social Norm}

Chewing betel was a widespread practice for thousands of years and was a social norm in Indonesia [29]. In the twentieth century, however, betel chewing was largely replaced by tobacco use. This substitution happened in a relatively short period, roughly between 1900 and 1950 [30, 31]. 
Smoking cigarettes presumably symbolized masculinity; thus, many people associated it with the 'male sphere'. In contrast, many consider smoking among women and girls impolite and ill-mannered. This norm, as observers believe, leads to the higher smoking prevalence among men than among women. Cigarettes have become a mandatory item to welcome guests at almost all important social gatherings, such as weddings, funerals, religious ceremonies, and community meetings [32]. In Indonesia, tipping is often followed by the phrase "ini uang rokoknya," or money for cigarettes [33, 34]. Moreover, smoking has been considered a basic daily necessity. The phrase "even money for cigarettes is hard to find" is a common expression referring to the difficulty in obtaining money for basic living [35]. Also, since Indonesia is a communal society, smoking behavior is a strong social norm. Indeed, some research has revealed that peer pressure is the most decisive factor in Indonesian smoking behavior [32, 36].

Many Indonesian social norms are influenced by religious value. The Indonesian Council of Ulama (MUI) has declared smoking to be haram, or forbidden, in public places, for pregnant women and children. The MUI is the country's highest authority on Islamic affairs and includes representatives of Nahdatul Ulama (NU). But, NU as Indonesia's largest Muslim association considers smoking for Muslims only objectionable (makruh), but not forbidden. Therefore, the majority of Indonesian populations consider smoking not forbidden by God.

\subsection{Incapable of Making Rational Decisions}

According to rational addiction theory, smoking is a rational decision in the economic realm [37]. Smokers as rational consumers face a trade-off between present pleasure and future costs. In front of them, there are two choices: becoming a smoker or not. They decide to smoke or continue to smoke if they are willing to pay the price-the cigarette price at present and high health costs in the future. In reality, more than $75 \%$ of Indonesian smokers started smoking before they were 18 years old. At that age, they are incapable of making a rational decision because their brains are not fully developed [38]. Meanwhile, the current tobacco regulations do not prohibit smoking or possession of cigarettes among adolescents. In fact, nearly three quarters of Indonesian smokers are categorized as uneducated people [4]. And it is safe to assume that adolescents and uneducated people are more easily manipulated to take up smoking than others.

Moreover, of the $50 \%$ of Indonesian smokers who try to quit, only about $3.3 \%$ successfully quit ${ }^{4}$. The inability of smokers to manage the withdrawal symptoms of nicotine addiction is the main factor in the failure of smoking cessation among smokers [39]. Interruption of nicotine intake results in temporal dysfunctional dorsolateral prefrontal cortex of the brain that significantly reduces the ability of the addicts to make rational decisions [40]. Therefore, their decision to take up cigarettes and continue smoking is not their genuine choice [41]. Further, it is difficult to protect adolescents and uneducated people from taking up cigarettes as well as promote smoking cessation among addicted smok- ers. Thus, adolescents are the main target of advertising and marketing of cigarettes in Indonesia [42].

\subsection{The Powerful Lobby of the Tobacco Industry Against Tobacco Control}

The tobacco industry has always been creative in the promotion of its products due to huge financial resources and a strong international network among transnational tobacco companies. To protect its products, the tobacco industry uses many tactics to challenge, weaken, and delay the implementation of tobacco control regulations. These include lobbying the government, politicians, and the media. In 2010, the Indonesian Tobacco Society Alliance (AMTI) and International Tobacco Growers' Association (ITGA) co-hosted a meeting in Jakarta with tobacco growers from Southeast Asia. They opposed a ban on tobacco ingredients and urged the Indonesian government to protect the tobacco growing sector.

It is commonly believed that Indonesian public officials have a special relationship with the tobacco industry for its support of legislative and presidential elections [43]. Thus, public policy against tobacco control would remain good for the industry. Moreover, some of Indonesia's richest and most politically connected individuals made their fortunes in tobacco [44]. The Vice-Chairman of the Indonesian Forum of Parliamentarians on Population and Development (IFPPD) in his capacity as Chairman of the Tobacco Farmer Association explained that the Indonesian government should not ratify FCTC due to the significant workforce contribution of the tobacco industry [45]. In 2006, the Sampoerna family started the Jurnal Nasional, a daily newspaper in Jakarta, which is a political proponent of the Merdeka Palace, Indonesia's White House [46]. In April 2012, the president's spokesperson said that a special team to discuss the possibility of the FCTC ratification had formed [47]. This statement, however, implied the weak intention of the government to ratify the FCTC. At the same time, the tobacco industry tries to win public opinion and promote their good image in the society, such as sponsorship, corporate social responsibility, and public relations [48]. Some observers even believe that the tobacco industry has secretly hired scientists to alter public opinion about tobacco-related diseases and secondhand smoke [49].

\subsection{Profit Maximization Behavior and Sustainability of the Tobacco Industry}

Tobacco control efforts would be best focused on adolescents as nearly $90 \%$ of new smokers come from this age group. However, the Indonesian government has not yet prohibited smoking for adolescents; thus, anybody of any age is free to smoke, including children. The last decree of tobacco control regulation, number 109/2012, prohibited the sale of cigarettes to children, but only via administrative sanctions. Thus, cigarette retailers continue to sell cigarettes to adolescents due to the profit maximization and prime source of new smokers $[43,50]$. Therefore, the tobacco industry has no other choice but to turn adolescents into smokers as early as possible. 
In the USA, due to the noncompliance of cigarette stores toward tobacco control regulations, the country has experienced only a slight decline in adolescents' access to cigarette sources-from $23.5 \%$ in 1999 to $18.3 \%$ in 2009 [51, 52]. In fact, nearly half of the adolescent buyers in a recent study were not asked to show identification when they bought cigarettes in stores [53]. Not surprisingly, more than three quarters of the adolescents said that cigarettes are easy to find in the market $[54,55]$. It is hard to draw any conclusion other than that the profit-maximizing behavior of the cigarette retailers and the sustainability of the tobacco industry seem to be more important than compliance with the laws and concern toward the younger generation [56].

\section{CIVIL SOCIETY AS THE LAST RESORT FOR TO- BACCO CONTROL IN INDONESIA}

The barriers on tobacco control mentioned above have made it difficult to obtain FCTC ratification and implement strong tobacco control regulations in Indonesia. The barriers have also caused an ineffective implementation of the current tobacco control regulations [57]. Therefore, civil society organizations are the last resort to resolve the tobacco control barriers in Indonesia. Indeed, some research shows that civil society organizations have played an important role in negotiation and implementation of tobacco control regulations [7, 58]. The framework convention alliance (FCA) is an association of civil society organizations and coalitions for tobacco control from around the world and were very influential during the negotiation of the WHO Framework Convention on Tobacco Control (FCTC). To influence policy positions of countries during the FCTC negotiation, the FCA mobilized civil society organizations to frame discussion of public health, publish a newsletter, and present shaming awards [7]. Similarly, in developed countries, civil society has played a very important role in the successful negotiation and implementation of strong tobacco control regulations [59].

Civil society plays five main roles: advocate, coalition builder, provider of evidence-based information, watchdog, and service provider [59-61]. Through these roles, tobacco control civil society organizations have bargaining power against public policy decision makers and the tobacco industry. Moreover, these roles make tobacco control civil organizations effective agents of change to resolve tobacco control barriers [59-62].

\subsection{Advocate for Tobacco Control}

Civil society tobacco control organizations can promote a favorable public opinion, propose tobacco control policies, and represent public health interest in court against the tobacco industry and state institutions [60, 61]. For example, some Indonesian anti-smoking NGOs, such as the Jakarta Residents Forum (FAKTA), the Indonesian Consumers Foundation (YLKI), the Institute for Combating Smoking (LM3), the Coalition for a Healthy Indonesia (KUIS), the Indonesian Women without Tobacco Foundation (YWITT), and the Indonesian Cancer Foundation (YKI) have been involved in lawsuits against the tobacco industry and state institutions.
In a lawsuit concerning a cigarette advertising series from a group of tobacco companies which aired from June to December 2001 on television, a group of anti-smoking NGOs were defeated by the tobacco companies in court. The NGOs accused the tobacco companies of violating cigarette advertising airtime on television, but the judges ruled in favor of the cigarette industry and even ordered the plaintiff to pay a penalty of IDR 100 million. The plaintiffs claimed that the advertising series violated Government Regulation No. 38/2000. However, the judges explained that the advertising had no connection with the broadcasting time but only contracted third parties to promote their products [63]. In a similar case, a group of four NGOs were defeated in a lawsuit against the president and the House of Representatives in 2011 over ratification of the FCTC. In their suit, the antismoking NGOs accused state institutions of failing to protect Indonesians from the dangers of smoking. The judges, nevertheless, found that these institutions had done their legal duty to protect citizens through tobacco control regulations that already existed.

Anti-smoking NGOs did not consider proper drafting of the indictments against tobacco companies or state institutions; thus, they often lost in court. Moreover, the lack of funds and human resources among civil society tobacco control organizations are the fundamental problems [59]. The defeat of the NGOs, some say, might also be said to have been caused by law enforcement officials being in favor of the tobacco industry interests [64]. In this context, civil society organizations should be empowered to represent consumer and public health since the government is more concerned with the political and economic aspects of the tobacco industry.

\subsection{Coalition Builder}

To build coalitions, the tobacco control civil society organizations can convene various organizations from different backgrounds and form general tobacco control alliances. The tobacco control alliance would thus more effectively mobilize the community and influence state institutions related to tobacco control policy [59, 60]. The National Commission on Tobacco Control (Komnas PT) was established in 1998 to coordinate and represent civil society in the fight for tobacco control in Indonesia and is composed of 23 organizations and leading individuals who have a common goal to protect the nation from the harm of smoking and early addiction among adolescents. The main activity of the commission is to promote the creation of tobacco control policies to high-level decision makers. In addition, its advocacy activities include creating a world of entertainment free of advertising, promotion, and sponsorship related to cigarettes. It must be added, however, the lack of resources for tobacco control activities places civil society organizations in direct competition with each other for the limited activity funding [26].

\subsection{Provider of Evidence-based Information}

As providers of evidence-based information, the tobacco control civil society organizations provide accurate information and balance public opinion about the tobacco control 
policies and health risks of smoking [58]. The organizations usually translate science-based evidence for policy makers, media, and the public. Fact sheets are a means frequently used by the organizations to make the complex topics such as price and taxation of cigarettes more accessible and understandable to the public. The Tobacco Control Support Centre (TCSC) is an agency under the Indonesian public health association that provides evidence-based information about the negative impacts of tobacco in Indonesia. In 2012, the Global Adult Tobacco Survey (GATS) publicized the results of an independent survey on tobacco in Indonesia. The evidence-based tobacco control programs have significantly reduced tobacco use among adults and adolescents in the USA [65]. Evidence-based information is meant to change the public perception about the health risks of smoking and stimulate strong tobacco control regulations [66]. However, the lack of local evidence-based information about the negative impacts of tobacco is one of the main barriers for Indonesian civil society organizations to change public perception about smoking. In addition, very little funding is available for tobacco control research of local scientificbased evidence.

\subsection{Watchdog}

As watchdogs, civil society organizations monitor and report on the implementation of tobacco control regulations. Ongoing monitoring by civil society organizations is an important way for tobacco control advocates to hold the government accountable for implementing the regulations appropriately [1]. This role involves conducting independent monitoring and evaluations that could permit unbiased determination of achievement in tobacco control policy. Report cards are examples of this watchdog role, and Southeast Asia Tobacco Control Alliance (SEATCA) usually provides the shadow reports on tobacco control in Southeast Asian countries, including Indonesia, to the WHO [67]. The Indonesian government's hesitance to implement current tobacco regulations and the inadequate human resources among civil society organizations to monitor the implementation of the regulations are a problematic combination for tobacco control in Indonesia.

\subsection{Service Provider}

Civil society organizations also play an independent service provider role. They provide anti-smoking campaigns, seminars, and counseling about tobacco-related diseases, as well as treatment for the poor. Providing services is a less controversial activity and fits well with the charitable role of the main stream of civil society. Furthermore, the service provider role makes civil society organizations powerful agents of change [58]. The community engagement through these services is necessary to change the social norm about tobacco use [66]. Some civil society organizations, such as TCSC, YLKI, Komnas PT, and the National Commission for Child Protection (Komnas Anak) have held seminars and counseling sessions about tobacco-related diseases. The lack of human and funding resources is a major obstacle for Indonesian civil society organizations in conducting their role as service providers.

\section{FUTURE DIRECTION}

The above discussion has revealed that civil society organizations are the last resort to overcome the substantial barriers to the ratification of FCTC and negotiation of strong tobacco control regulations in Indonesia. However, Indonesian civil society organizations face the challenge of building their capacities in spite of scarce resources. Therefore, we propose several policies, such as fund allocation for tobacco control, tobacco control research, and election of legislative and public officials who support strong tobacco control regulations.

\subsection{Tobacco Control Fund}

According to the World Bank, tobacco control policies are considered cost-effective toward health care due to the high cost of tobacco-related diseases [5], and tobacco control is one of the most rational evidence-based policies in health care [68]. Government and civil society organizations require sustainable funding resources to conduct tobacco control programs such as mass media campaigns to prevent initiation among youth, promotions to stop smoking among adults, public information about the health consequences of smoking, and tobacco control research [57]. Tobacco control funds derived from a surcharge on tobacco is also an effective way of taxing disease-causing products to promote health $[69,70]$. Moreover, tobacco taxes have immediate health promotion benefits because they increase the cigarette price and thus discourage smoking among adolescents and poor people [71]. This fund would be used by the government to promote health by working with civil society tobacco control and community-based organizations to carry out health promotion programs and initiatives [72]. Therefore, Indonesian civil society organizations should advocate for the tobacco control fund obtained from tobacco excise taxes.

\subsection{Local Tobacco Control Research}

Knowledge and proper understanding about the negative impacts of tobacco will change the public perception of smoking. Thus, local scientific evidence-based information about the negative impact of tobacco can be used to change public perception [73]. Conducting independent research is essential to convince the community about the negative impacts of tobacco. Very little local research, unfortunately, has focused on the health impacts of smoking kreteks, despite evidence showing that eugenol caused negative health impacts $[17,18]$. Moreover, grants to support independent researchers in tobacco agriculture, industry, economics, and epidemiology would encourage the mobilization of the academic community to provide scientific local evidence. Local tobacco control research would provide accurate information to civil society organizations and professionals active in tobacco-related issues and better inform the public debate [59]. Moreover, public health experts and policy decision makers are increasingly demanding that the rationale for tobacco control policies should be based on local evidence [74]. Tobacco control policies are most effective when they are based on local research findings, so such policies should be appropriate for the local conditions and characteristics of society [75]. Therefore, civil society should be intensely 
involved in local tobacco control research to provide local evidence to the community and public decision makers.

\subsection{Mobilizing the Community to Give their Vote for Tobacco Control}

Effective prevention policy is a function of three factors: a knowledge base, a social strategy, and political will [73]. Some case studies have confirmed that leadership in tobacco control is a key component of success [76]. Strong tobacco control regulations reflect the increased political commitment of the government and parliament to public health and tobacco control [57]. The cigarette industry, however, is still a main contributor to government revenue. In fact, it was the only sector not hit by the financial crisis of 1997 and 1998 due to its addictive substance [64]. For many years, only hesitant steps have been taken to introduce tobacco control policies on the political and public health agenda. Therefore, to increase political will on tobacco control, civil society organizations should mobilize the community to vote for legislative and executive official candidates who support strong tobacco control regulations.

\section{CONCLUSION}

Civil society organizations are the most important component of success in resolving the barriers of tobacco control in Indonesia. The ratification of FCTC would be an important first step to provide legal standing for civil society organizations to play these roles. Tobacco control funds would resolve the fundamental problem of civil society organizations to conduct their functions. Finally, Indonesian civil society organizations should intensively mobilize the community to vote for tobacco control.

\section{CONFLICTS OF INTEREST}

The author(s) confirm that this article content has no conflicts of interest.

\section{ACKNOWLEDGEMENT}

None declared.

\section{REFERENCES}

[1] World Health Organization. Framework Convention on Tobacco Control (FCTC). Geneva: WHO Press 2003.

[2] Aditama TY, Pradono J, Rahman K, et al. Global Youth Tobacco Survey (GYTS) Indonesia $2006 . \quad$ Availabe at: http://www.searo.who.int/LinkFiles/GYTS_Indonesia-2006.pdf [Accessed 12 January 2012].

[3] Global Youth Tobacco Survey. Fact sheet of Indonesia (Ages 1315). 2009. WHO Regional office for South East Asia. Available at: http://www.searo.who.int/LinkFiles/GYTS_IndonesiaFactsheet200 9.pdf [Accessed 12 January 2012].

[4] World Health Organization. Global Adult Tobacco Survey (GATS): Indonesia report 2011. Jakarta: WHO Regional Office for South East Asia 2012.

[5] Lightwood JM, Dinno A, Glantz SA. Effect of the California tobacco control program on personal health care expenditures. PLoS Med 2008; 5: e178.

[6] Kosen S, Aryastami K, Usman Y, et al. Study on medical expenditure and burden of major tobacco attributed diseases in Indonesia. 2009. Available http://whoindonesia.healthrepository.org/bitstream/123456789/601/ 1/NIHRD\%20-

\%20Study\%20on\%20Medical\%20Expenditures\%20and\%20Burde n\%20of\%20Major\%20Tobacco...\%20\%28INO\%20FFC\%20011\% 20SE-09-229815\%29.PDF [Accessed 22 February 2013].

Mamudu HM, Glantz SA. Civil society and the negotiation of the Framework Convention on Tobacco Control. Global Public Health 2009; 4(2): 150-68.

[8] Indonesian Ministry of Finance. Financial memorandum and Indonesian budget. 2012. Available at: http://www.anggaran.depkeu.go.id/Content/11-0818,\%20NK\%20RAPBN\%202012.pdf [Accessed 15 September 2012].

[9] Rachmat M. Development of national tobacco economy: Developed country policy and lesson learned for Indonesia. 2010. Available at: http://isjd.pdii.lipi.go.id/admin/jurnal/81106783_16932021.pdf [Accessed 25 November 2012].

[10] Statistics Indonesia (BPS). Jumlah tenaga kerja industri besar dan sedang menurut sub sektor, 2004-2010. Available at: http://www.bps.go.id/tab_sub/view.php?tabel=1\&daftar=1\&id_sub yek=09\&notab=11 [Accessed 30 April 2013].

[11] Barber S, Ahsan A, Adioetomo SM, Setyonaluri D. Tobacco economics in Indonesia. Paris: International Union against Tuberculosis and Lung Disease 2008.

[12] Semba RD, Kalm LM, de Pee S, Ricks MO, Sari M, Bloem MW. Paternal smoking is associated increased risk of child malnutrition among poor urban families in Indonesia. Public Health Nutr 2007; 10: 7-15

[13] Best CM, Sun K, de Pee S, Sari M, Bloem MW, Semba RD. Paternal smoking and increased risk of child malnutrition among families in rural Indonesia. Tobacco Control 2008; 17: 38-45.

[14] de Beyer J, Lovelace C, Yürekli A. Poverty and tobacco. Tobacco Control 2001; 10: 210-1.

[15] Semba RD, de Pee S, Sun K, Best CM, Sari M, Bloem MW. Paternal smoking and increased risk of infant and under-5 child mortality in Indonesia. Am J Public Health 2008; 98(10): 1824-6.

[16] Polzin GM, Stanfill SB, Brown CR, Ashley DL, Watson CH. Determination of eugenol, anethole, and coumarin in the mainstream cigarette smoke of Indonesian clove cigarettes. Food Chem Toxicol 2007; 45(10): 1948-53.

[17] Guidotti TL. Critique of available studies on the toxicology of kretek smoke and its constituents by routes of entry involving the respiratory tract. Arch Toxicol 1989; 63: 7-12.

[18] Lin F. Trans-Anethole. US Food and Drug Administration 1998 Available

http://www.inchem.org/documents/jecfa/jecmono/v28je10.htm

[Accesses 29 April 2013].

[19] Givel M. A comparison of US and Norwegian regulation of coumarin in tobacco products. Tobacco Control 2003; 12(4): 401-5.

[20] World Health Organization. Advancing knowledge on regulating tobacco products. Geneva: WHO Press 2000.

[21] Hanusz M. Kretek. The culture and heritage of Indonesia's clove cigarettes. Jakarta: Equinox Publishing 2000.

[22] International Agency for Research on Cancer. Tobacco smoke and involuntary smoking. Lyon: IARC Press 2004.

[23] Doll R, Peto R, Boreham J, Sutherland I. Mortality in relation to smoking: 50 years' observations on male British doctors. Br Med J 2004; doi:10.1136/bmj.38142.554479.

[24] U.S. Centers for Disease Control and Prevention. Perspectives in disease prevention and health promotion smoking-attributable mortality and years of potential life lost in United States, 1984. Morbid Mortal Week Rep 1997; 46(20): 444-51.

[25] Reynolds C. The fourth largest market in the world. Tobacco Control 1999; 8: 89-91.

[26] Achadi A, Soerojo W, Barber S. The relevance and prospects of advancing tobacco control in Indonesia. Health Policy 2005; 72: 333-49.

[27] Detik Health. Soal beli rokok ketengan tak diatur di PP tembakau. 2013. Available at: http://health.detik.com/read/2013/01/09/160725/2137466/766/soal- 
beli-rokok-ketengan-tak-diatur-di-pp-tembakau?l771108bcj. Accessed 20 Marc 2013.

[28] Hadiatmodjo F. YPKKI: Perusahaan rokok raksasa akan mandulkan PP 109/2012. 2013. Available at: http://www.itoday.co.id/politik/ypkki-perusahaan-rokok-raksasaakan-mandulkan-pp-1092012. Accessed 6 March 2013.

[29] Lewin L. Phantastica: Narcotic and stimulating drugs, their use and abuse. New York: E.P. Dutton \& Co. 1964.

[30] Reid A. From betel chewing to tobacco smoking in Indonesia. J Asian Stud 1985; 44(3): 529-47.

[31] Aditama TY. Rokok dan kesehatan. Jakarta: UI Press 1996.

[32] $\mathrm{Ng} \mathrm{N}$, Weinehall L, Öhman A. If I don't smoke, I'm not a real man'-Indonesian teenage boys' views about smoking. Health Educ Res 2007; 22(6): 794-804.

[33] Nina. Rokok dalam budaya. 2009. Available at: http://naninaninana.multiply.com/journal/item/68 [Accessed 15 Marc 2013].

[34] Nahar M. Mentalitas uang rokok. 2012. Available at: http://wasathon.com/gaya_hidup/read/mentalitas_uang_rokok/ [Accessed 26 Marc 2013].

[35] Litamahuputty B. Ternate Malay: Grammar and texts. JK Utrecht: LOT 2012.

[36] Smet B, Maes L, Clercq LD, Haryanti K, Winarno RD. Determinants of smoking behavior among adolescents in Semarang, Indonesia. Tobacco Control 1999; 8: 186-91.

[37] Becker GS, Murphy KM. A theory of rational addiction. J Polit Econ 1988; 96(4): 675-700.

[38] Giedd JN, Blumenthal J, Jeffries NO, et al. Brain development during childhood and adolescence: A longitudinal MRI study. Nat Neurosci 1999; 2(10): 861-3.

[39] U.S. Department of Health and Human Services. How tobacco smoke causes disease: The biology and behavioral basis for smoking-attributable disease: A report of the Surgeon General. Atlanta, GA: U.S. Department of Health and Human Services, Centers for Disease Control and Prevention, National Center for Chronic Disease Prevention and Health Promotion, Office on Smoking and Health 2010

[40] Hayashi T, Koa JH, Strafellaa AP, Daghera A. Dorsolateral prefrontal and orbitofrontal cortex interactions during self-control of cigarette craving. Proc Natl Acad Sci 2013; doi:10.1073/pnas.1212185110.

[41] Goodin RE. The ethics of smoking. Ethics 1989; 99(3): 574-624.

[42] Nichter M, Padmawati S, Danardono M, Ng N, Prabandari Y, Nichter M. Reading culture from tobacco advertisements in Indonesia. Tobacco Control 2009; 18: 98-107.

[43] Kin F, Assunta M. Tobacco industry interference. Bangkok: SEATCA 2009. Available at: http://www.healthjustice.ph/uploads/Tobacco\%20Industry\%20Inter ference\%20SEATCA\%20Report.pdf [Accessed 9 Marc 2013].

[44] Schonhardt S. Is Indonesia, one of big tobacco's last frontiers, closing? 2013. Available at: http://www.cnbc.com/id/100516212 [Accessed 13 March 2013].

[45] Suara M. Jangan tutup pabriknya, cari solusinya. 2005. Available at: http://www.suaramerdeka.com/harian/0504/26/nas05.htm [Accessed 19 Marc 2013].

[46] Public Integrity. Public health suffers as Indonesia ignores calls for tobacco reform. 2012. Available at: http://www.publicintegrity.org/2011/09/09/6062/public-healthsuffers-indonesia-ignores-calls-tobacco-reform [Accessed 19 March 2012].

[47] Rahman A. Talks over new Indonesian tobacco regulation continue to drag on 2010. Available at: http://www.thejakartaglobe.com/home/talks-over-new-indonesiantobacco-regulation-continue-to-drag-on/404407 [Accessed 13 March 2013].

[48] Southeast Asia Tobacco Control Alliance. Perfect deception. 2008. Available at: http://resources.seatca.org/Perfect Deception.pdf [Accessed 14 April 2012].
[49] Muggli ME, Hurt RD, Blanke DD. Science for hire: A tobacco industry strategy to influence public opinion on secondhand smoke. Nicotine Tob Res 2003; 5: 303-14.

[50] Reimondos A, Utomo ID, McDonald P, Hull T, Suparno H, Utomo A. Smoking and young adults in Indonesia 2012. Available at: http://adsri.anu.edu.au/sites/default/files/research/transition-toadulthood/Policy_Background_\%232_Smoking.pdf [Accessed 21 March 2013].

[51] U.S. Centers for Disease Control \& Prevention. Youth risk behavior surveillance - United States, 2009, CDC surveillance summaries. Morbid Mortal Week Rep 2010; 59: SS-5.

[52] U.S. Centers for Disease Control \& Prevention. Youth risk behavior surveillance - United States, 1999, CDC surveillance summaries. Morbid Mortal Week Rep 2000; 49: SS-5.

[53] U.S. Centers for Disease Control \& Prevention. Youth risk behavior surveillance - United States, 2005, CDC surveillance summaries. Morbid Mortal Week Rep 2006; 55: SS-5.

[54] Johnston LD, O’Malley PM, Bachman JG, Schulenberg JE. Monitoring the future national results on adolescent drug use: Overview of key findings, 2010. Ann Arbor: Institute for Social Research, University of Michigan 2011.

[55] Johnston LD, O’Malley PM, Bachman JG, Schulenberg JE. Monitoring the future national results on adolescent drug use: Overview of key findings, 2006. Bethesda, MD: National Institute on Drug Abuse 2007.

[56] Robinson J, Amos A. A qualitative study of young people's sources of cigarettes and attempts to circumvent underage sales laws. Addiction 2010; 105(10): 1835-43.

[57] World Health Organization. European strategy for tobacco control. Copenhagen: WHO Regional Office for Europe 2002.

[58] Open Society Institute. Taking on Goliath civil society's leadership role in tobacco control. 2007. Available at: http://www.opensocietyfoundations.org/reports/taking-goliathcivil-societys-leadership-role-tobacco-control [Accessed 20 March 2013].

[59] Novotny TE, Mamudu HM. Progression of tobacco control policies: Lessons from the United States and implications for global action. Washington, DC: The World Bank 2008.

[60] World Health Organization. Stop the global epidemic of chronic disease: A practical guide to successful advocacy. Geneva, WHO Press 2006.

[61] Champagne BM, Ernesto Sebrié E, Verónica Schoj V. The role of organized civil society in tobacco control in Latin America and the Caribbean. Salud Publica de Mexico 2010; 52(suppl 2): S330-9.

[62] Merzel C, D'Afflitti J. Reconsidering community-based health promotion: Promise, performance, and potential. Am J Public Health 2003; 93(4): 557-74.

[63] Gatra. Kalah, penggugat didenda Rp 100 Juta. 2003. Available at: http://arsip.gatra.com/2003-04-01/versi_cetak.php?id=26774 [Accessed 26 March 2013].

[64] Arnez M. Tobacco and kretek: Indonesian drugs in historical change. Shouth East Asia Studies 2009. Available at: http://www.seas.at/aseas/2_1/ASEAS_2_1_A4.pdf [Accessed 10 March 2013].

[65] U.S. Centers for Disease Control \& Prevention. Youth risk behavior surveillance - United States, 1999, CDC surveillance summaries. Morbid Mortal Week Rep 2000; 49: SS-5.

[66] Nathanson C. Disease prevention as social change: Toward a theory of public health. Popul Dev Rev 1996; 22(4): 609-37.

[67] South East Asia Tobacco Control Alliance (SEATCA). The ASEAN tobacco control report 2012. Available at: http://seatca.org/dmdocuments/ASEAN\%20Tobacco\%20Control\% 20Report\%202012.pdf [Accessed 25 April 2013].

[68] Taylor AL, Bettcher DW. WHO Framework Convention on Tobacco Control: A global "good" for public health. Bull WHO 2000; 78(7): 920-9.

[69] World Health Organization. Global status report on non communicable diseases. Geneva: WHO Press 2010.

[70] Vathesatogkit P, Lian TY. Lessons learned in establishing a health promotion fund. Bangkok: SEATCA 2011. 
[71] Gruber J, Koszegi B. Is addiction "rational”? Theory and evidence. Quart J Econ 2001; 116: 1261-303.

[72] World Health Organization. The establishment and use of dedicated taxes for health. Manila: WHO Western Pacific Regional Office 2004.

[73] Richmond J, Fein R. The health care mess: How we got into it, and what it will take to get us out. Cambridge, MA: Harvard University Press 2007.
[74] World Health Organization. WHO technical report series 945. In: The scientific basis of tobacco product regulation. Geneva: WHO Press 2006.

[75] Warner KE. The role of research in international tobacco control. Am J Public Health 2005; 95: 976-84; doi:10.2105/AJPH.2004.046904.

[76] de Beyer J, Waverly L (editors). Tobacco control policy: Strategies, successes, and setbacks eight country studies. Washington, DC: Research for International Tobacco Control and World Bank 2003.

Received: August 26, 2013

Revised: October 21, 2013

Accepted: October 28, 2013

(c) Tandilittin and Luetge; Licensee Bentham Open.

This is an open access article licensed under the terms of the Creative Commons Attribution Non-Commercial License (http://creativecommons.org/licenses/by-nc/3.0/) which permits unrestricted, non-commercial use, distribution and reproduction in any medium, provided the work is properly cited. 